\title{
Water relations and growth response to drought stress of Prosopis tamarugo Phil. A review.
}

\author{
Alson Time ${ }^{1}$, Marco Garrido $^{1}$, Edmundo Acevedo ${ }^{1 *}$

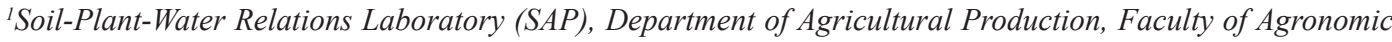 \\ Sciences. University of Chile. PO Box 1004. Santiago. Chile. *Corresponding author: eacevedo@uchile.cl
}

\begin{abstract}
Understanding the physiological mechanisms of response that allow plants to survive under suboptimal conditions such as drought stress is of particular interest, because of global climate change that threat the suitability of most terrestrial habitats for plant growth, as well as habitat disturbance of desert plants due to water extraction for human supply. Prosopis tamarugo Phil. of the Pampa del Tamarugal is frequently subjected to drought stress due to groundwater extraction for urban areas, mining industry and agriculture supply. The aim of this review is to analyze information concerning the plant growth response to drought stress and specifically $P$. tamarugo water relations and growth response to drought stress. P. tamarugo, being a desert plant, has physiological mechanisms that permit its adaptation to extreme environmental conditions like the Pampa del Tamarugal. It has mechanisms as osmotic adjustment, that allow some growth through osmoregulation; changes the angle of its leaflets to avoid high levels of radiation in the afternoon; partially closes its stomata to decrease water loss; maintains high stomata conductance to deal with increasing temperature and atmospheric demand.
\end{abstract}

Keywords: Water potential, drought, water depletion, osmotic potential 


\section{Introduction}

One of the most limiting factors of plant growth is water. Consequently, plants have developed mechanisms to fight stress caused by water limitation. When an environmental stress factor exceeds the threshold resistance, the survival of the woody plant may depend on the activation of physiological and biochemical mechanisms of resistance, on the flexibility of these mechanisms, on the compensatory abilities and on the intensity and duration of the stressor (Mandre, 2002). At present the mortality rate in most woodland community biomes has experienced an increase associated to increases in temperature and a higher incidence of drought (Williams et al., 2013), along with human intervention that can generate stresses in the future or significantly affect an already stressed environment (Frelich, 2002). This is the case of Pampa del Tamarugal (Atacama Desert, Chile), a hyperarid desert dominated by Prosopis tamarugo, a strict phreatophyte growing under water table depletion conditions due to groundwater extraction for urban areas, mining industry and agriculture supply (Rojas and Desargues, 2007).

The short effect of low soil water content on plants has been studied extensively (Schimel et al., 2007). Soil water content depletion is known to reduce plant growth and soil microbial activity due to low water availability and nutrient diffusion due to water deficit (Xue et al., 2016).

Water deficit affects a large range of variables and functions in plants, such as stomata functioning (Tardieu and Simonneau, 1988), hydric traits as predawn, mid-day water potential and xylem hydraulic conductivity (Rood et al., 2000 and Cooper et al., 2003), and growth traits like twig elongation rate, leaf shoot ratio and specific leaf area (Lambers, 1998 and Guan et al. 2003).
The stomatal regulation determines water consumption of plants and affects the ability to survive under conditions of drought stress. In a drought stress condition, the soil and plant water content affect the opening of the stomata. Some data demonstrated that stomata remain unaffected until the leaf water potential drops to some critical threshold value (Hsiao and Acevedo, 1974). The mechanism of stomatal closure is considered as one of the highest factors of photosynthesis limitation (Flexas et al. 2014). It depends on the plant stomatal behavior (McDowell et al., 2008); under drought stress stomatal earliest closure is typical of isohydric plants. By contrast, anisohydric plants delay closing their stomata in water shortage condition, enhancing gas exchange and let the leaf water potential decrease as the soil water potential is declining (Tardieu and Simonneau, 1988). Isohydric plants tend to experience a negative carbon balance, while anisohydric plants experiment low water potential which induces hydraulic failure by xylem cavitation and embolism.

Being a desert plant, tamarugo has developed some mechanisms of adaptation to survive its environmental conditions. Such mechanisms include the capacity to maintain high stomata conductance when subjected to increasing temperature and atmospheric water demand (Lehner et al., 2001; Delatorre et al., 2008) by partially closing its stomata to decrease water loss and change the angle of its leaflets to avoid high levels of radiation in the afternoon (Chávez et al., 2013a); it has osmoregulation, which is a solute accumulation in the cells allowing a positive turgor pressure development in spite of the low water potential.

In this review, we summarize current understanding about woody plants growth mechanisms response to water deficit, with the objective of analyzing the situation 
of $P$. tamarugo, a phreatophyte growing under groundwater depletion conditions in the Pampa del Tamarugal.

\section{Review}

\subsection{Situation of P. tamarugo in the Pampa del Tama-} rugal.

Prosopis tamarugo Phil. (tamarugo) is a native legume tree that grows in the Pampa del Tamarugal, Atacama Desert, region of Tarapaca, Chile (Acevedo et al., 1985a). It belongs to the family Leguminosae, subfamily Mimosoideae. Prosopis is a genus with 44 species, of which three are native to Southeast Asia, one to tropical Africa (Galera, 2000) and 40 species are native to America (MINAGRI, 2006). The plants in this genus occupy large areas of soil and diverse climates, from humid subtropical to cold xeric, and from sea level to over $3.000 \mathrm{~m}$ altitude (Galera, 2000). In Chile, 6 species represent the genus. Prosopis tamarugo is an endemic species that is under threat of extinction, according to the IUCN (International Union for Conservation of Nature) and is listed as vulnerable in the red book of the conservation status of the Chilean flora (MMA, 2012).

Tamarugo grows in salt flats of arid areas where the water table depth is between 2 and $18 \mathrm{~m}$ (Acevedo and Pastenes, 1983; Habit, 1985). The species is very tolerant to salinity and has active nitrogen fixing nodules on its roots (Acevedo et al., 2007).

Tamarugo is a species described as halophyte, tolerant to high salt levels; it is a deciduous tree, prickly, with open cup, with two growth habits in the same tree, a cup formed by rigid and erect branches, and a growth habit in which the branches tend to bend.

Tree height reaches between 8 and $20 \mathrm{~m}$ under favorable conditions, $15-20 \mathrm{~m}$ of cup diameter and trunks 0.5 to $0.8 \mathrm{~m}$ in diameter (Sudzuki, 1985). The foliage consists of compound leaves which have glands that allow movement of the leaflets to cope with radiation in the environmental conditions in which they live (Chávez et al., 2013a).

It has a capacity to maintain high stomata conductance when subjected to increasing temperature and atmospheric water demand (Lehner et al., 2001; Delatorre et al., 2008). Chávez et al. (2013a) indicated that tamarugo is a plant capable of changing the angle of its leaflets in order to avoid high levels of radiation in the afternoon. This ability would be associated with the level of turgor in pulvinar structures in the leaf, and the authors note that individuals undergoing certain threshold of drought stress would be less capable of carrying out this process, therefore being more susceptible to damage by photoinhibition (Chávez et al., 2013b and Chávez et al., 2016).

Tamarugo blooms all year around, with a typical spring bloom that peaks in October and one or two flowering peaks in winter, between late April and July, varying in number and intensity (Acevedo et al., 2007).

Tamarugo has a double root system: one pivoting, deep and made of three to four thick roots lignified and unbranched, and the other consisting of a large mass of shallow lateral roots, covering a perimeter approximately equal to the tree canopy diameter (Sudzuki, 1985). The superficial lateral roots are responsible for the accumulation of moisture in the soil in the area under the canopy of the tree, phenomenon described as the theory of "water elevator" (Richards and Cladwell, 1987; Aravena and Acevedo, 1985) which states that during the night when the stomata are closed the deep roots absorb water from the water table or from wetter areas of soil, and transport it to the drier surface layers where they release the water to the soil.

Tamarugo is subjected to drought stress due to ground water extraction for urban areas, mining industry and agriculture supply, that is generating depletion of 
the water table of the aquifer (Rojas and Desargues, 2007), and generates an unbalance in the tamarugo water budget.

\subsection{Tamarugo physiological responses to water deficit.}

A plant is under stress when it is subjected to a condition significantly different to the optimal for development, the optimum requirement condition is different among different species and varieties and therefore they are susceptible to a particular stress (Hsiao and Acevedo, 1974; Valladares, 2004). Besides the process of cell growth, inhibition of cell division, inhibition of wall and protein synthesis, accumulation of solutes, closing of stomata, and inhibition of photosynthesis; drought stress induced by water deficit also affects leaf water potential, osmotic potential, the relative water content and transpiration rate of species, and then twig growth rate. However, the tolerance range of a species to an unfavorable factor is unique. In water deficit situations, each species has the ability to develop its own physiologic responses of adaptation to the environment and the degree of adaptation to drought may vary considerably within genera or species. In experiences reported by Sanchez-Blanco et al. (2002), it is shown how resistance mechanisms developed by two species to confront a water deficit situation are different. For example, in Cistus albidus Phil. the main limiting factor of growth was cell expansion, whereas in Cistus monspeliensis Phil. photosynthesis was the limiting factor, but both species responded to water deficit by developing avoidance mechanisms based on stomatal closure, a reduction in leaf area and root hydraulic conductivity, and epinasty, which can be considered as complementary mechanisms for regulating transpiration. There are evidences that tamarugo has the ability to regulate its water demand via partial stomatal closure and through foliage loss (Chavez et al. 2016; Ortiz et al. 2012).
How plants respond generally to drought stress? The plants' response to water stress in terms of their physiology at the entire level is complicated and changes can be made via adaptive or destructive mechanism (Khalatbari et al. 2015). Plant species and variety, duration and intensity of water deficit, environmental conditions, alterations in water demand from the atmosphere and plant growth as well, are number of factors that play crucial roles when a plant is under drought stress (Chaves et al., 2002; Khalatbari et al., 2015).

Chapin (1991) evidenced that all plants respond to stress of many types in the same way, besides plants also have a centralized system of stress response that enables them to respond to any physiological stress, regardless of the nature of that stress. However, ecologists and physiologists characterize plants from lowresource environment to stress in a different way. According to ecologist view, slow growth, low photosynthetic rate, and low capacity for nutrient uptake (Chapin, 1980; Grime, 1977) are suites of traits that characterize plants from all low-resource environments like deserts, tundra, shaded understory, and infertile soils. For physiologists, in addition, change in hormonal balance, high frequency production of abscisic acid and less cytokinins are considered as responses of individual plants to most environmental stresses (Chapin and Wardlaw, 1988). These hormonal changes are considered by the author as the basis of direct reduced growth in response to environmental stress and low availability of a resource. Plants always develop specific mechanisms to respond to specific stresses; some plants adjust osmotically in response to salt and drought stress (Morgan, 1984), some others increase their potential to absorb nutrients in response to nutrient stress (Lee, 1982), and other plants modify the quantity and balance of photosynthetic enzymes in response to shade or light stress (Evans, 1989). In the case of Prosopis tamarugo, it has been proved its ability to perform osmotic adjustment for favoring the 
maintenance of a positive pressure potential and an active metabolism under drought stress (Acevedo et al., 1985b; Acevedo et al., 1985c). But, no evidences about hormonal changes and nutrient absorbing potential in response to stress in tamarugo was reported.

Additionally, water deficit affects many variables and functions in tamarugo plants, such as stomata functioning (Garrido, et al., 2016, Time, 2017), hydric traits as pre-dawn, mid-day water potential and xylem hydraulic conductivity (Garrido et al., 2016; Time, 2017) and growth traits like twig elongation rate and specific leaf area (Time, 2017) have been reported. The performance of these and other traits and processes, may determine growth capacity and tamarugo plant survival as suggested by McDowell et al., (2008). However, the stomatal regulation determines water consumption of plants and affects the ability to survive under conditions of drought stress. In a drought stress condition, the soil and plant water content affects the opening of the stomata. It depends on the plant stomatal behavior (McDowell et al., 2008); under drought stress, stomatal earliest closure is typical of isohydric plants. By contrast, anisohydric plants delay closing their stomata in water shortage condition, enhancing gas exchange and let the leaf water potential decrease as the soil water potential is declining (Tardieu and Simonneau, 1988). Isohydric plants tend to experience a negative carbon balance, while anisohydric plant experiment low water potential which may induce hydraulic failure by xylem cavitation and embolism. Referring to tamarugo, it has been proved that undergoes an anisohydric behavior (Time, 2017) facing drought stress. It lets the leaf water potential decrease as the soil water potential decreases (Time, 2017), and the partial stomatal closure strategy reported by Chavez et al. (2016) and Ortiz et al. (2012) was reflected in the tendency to the decrease of the stomatal conductance. However, tamarugo can maintain a high stomatal conductance at low leaf water potential (Time, 2017).
Additionally, it has been reported that drought stress affects plant growth in other species, by decreasing cytokinin transport from roots to shoots and increasing leaf $\mathrm{ABA}$, and these changes in hormonal balance provoke changes in cell-wall extensibility (Blackman and Davies, 1985).

However, there are observations that suggest the decline in photosynthesis is not directly responsible for drought-induced growth declines. According to Hsiao et al. (1976), the increase of carbohydrate concentration is product of mild drought stress. Munns et al. (1982) and Wardlaw (1969), on the other hand, attributed the decline in leaf growth as a precedent of the decline in dry weight accumulations. According to these observations, drought may cause a reduction in growth most directly by altering hormonal balance, but this decline in growth is more associated and interconnected with changes in plant nutrition, carbon balance, and water relations. Referring to the carbon balance, changes in carbohydrate demand from growth and respiration and supply from photosynthesis in woody plants is a reflection of fluctuations in plant carbon balance (Mitchell et al., 2014). A positive carbon balance occurs in plants when the photosynthesis produces more carbohydrates than is required by growth, respiration and defense; subsequently, photosynthesis may decline in response to these carbon sink limitations (Pinkard et al., 2011). As mentioned, until now as far as it is known, there is no work reported on how tamarugo regulates its hormonal balance under drought stress.

\subsection{Stomatal control over Tamarugo plant growth.}

The relationship between stomatal opening and leaf water status has been much documented ultimately. The stomatal regulation determines water consumption of plants and affects the ability to survive under conditions of drought stress. In a drought stress condition, the soil and plant water content affect the opening of 
the stomata. Tardieu and Simonneau (1988) indicated that the stomatal behavior is regulated by the concentration of abscisic acid (ABA) and that its response may or may not be regulated by the leaf water potential $(\Psi \mathrm{L})$, which in turn is associated to the atmospheric demand (vpd). The stomatal opening is also dependent on the relationship among hormonal balance and other factors under good water availability. Thus, partial closure of stomata has been reported in other species (Garcia, 2006) when the proportion of ABA was greater than that of cytokinins. Hence, when water loss by transpiration cannot be compensated by the water absorption, a hormonal imbalance is produced, increasing the proportion of abscisic acid, the potassium concentration in guard cells decreases, they lose turgor and stomata are partially closed. Thus, by closing the stomata, stomatal conductance decreases limiting the evaporation of water and reducing the $\mathrm{CO}_{2}$ fixation. On the other hand, the plants have the capacity to regulate their carbon and water balance under drought of differing intensities and duration (McDowell et al., 2008; Allen et al., 2010). When a plant is exposed to low-intensity but long duration drought, it may maintain water status above critical water potential thresholds but deplete stored carbohydrates to lethal limits. In addition, under high-intensity drought, incapacity to regulate plant water status above critical thresholds will promote xylem cavitation and death through dehydration (Patrick et al., 2013).

Plant strategies to cope with water deficits are the product of adaptive traits that enable resistance of plant functioning to changes in water supply and recovery when water deficit is relieved (Mitchell et al., 2014). Gas exchange, growth, water transport and carbon (C) metabolism reduce during drought according to their respective sensitivities to declining water status.

Theoretical relationships, based on the hydraulic framework, between the temporal length of drought (duration) and the relative decrease in water availabil- ity (intensity) have been approached by McDowell et al. (2008) and Allen et al. (2010) in studies on the mechanisms of drought-related mortality in plants. McDowell et al. (2008), hypothesized in a general framework that plant mortality is due to biotic agents, demographics, hydraulic failure, and carbon starvation. In addition, the relevance of these different mechanisms is related to the intensity and duration of drought stress. According to McDowell et al. (2008), the hydraulic-failure hypothesis predicts that reduced soil water supply coupled with high evaporative demand causes xylem conduits and the rhizosphere to cavitate (become air-filled), stopping the flow of water and desiccating plant tissues. Hydraulic failure may be particularly likely if drought is sufficiently intense that plants run out of water before they run out of carbon. The carbon-starvation hypothesis predicts that stomatal closure to prevent hydraulic failure causes photosynthetic uptake of carbon to diminish and the plant starves because of continued metabolic demand for carbohydrates. This process may be exacerbated by photoinhibition or increased respiratory demands associated with elevated temperatures during drought. Under water deficit, the plant stomatal regulation strategy also determines the carbon gain and water consumption of plants and affects the ability to survive under conditions of drought stress.

The relationship between $\mathrm{CO}_{2}$ assimilation and stomata opening affected by drought stress has been reported by many old and recent data. Hsiao (1973) established that there are nonstomatal effects of stress in suppressing photosynthesis in addition to stomatal effect in some species when stress is sufficiently severe. He lied the basis for these effects to alter transport parameters for $\mathrm{CO}_{2}$ from the inter-cellular space to the chloroplast or the altered ability of chloroplast to photosynthesize, and to an increase in respiration in the leaf.

Under drought stress, the tamarugo tends to decrease water loss by partially closing their stomata (Calde- 
ron et al. 2015) in search of a water balance, and a translocation of assimilates to the root zone may occur (Lambers et al., 1998).

\subsection{Assessing P. tamarugo plant growth through iso- topic composition analysis.}

In nature, there are two stable isotopes of carbon, ${ }^{12} \mathrm{C}$ (98.982\%) and ${ }^{13} \mathrm{C}(1.108 \%)$, and three stable isotopes of oxygen, ${ }^{16} \mathrm{O}(99.759 \%),{ }^{17} \mathrm{O}(0.037 \%)$ and ${ }^{18} \mathrm{O}(0.204 \%)$ (Dawson et al., 2002), being the ${ }^{12} \mathrm{C}$ and ${ }^{16} \mathrm{O}$ the most abundant source of stable isotope of carbon and oxygen respectively. The total abundance of ${ }^{13} \mathrm{C}$ relative to ${ }^{12} \mathrm{C}$ in plant tissue (isotopic ${ }^{13} \mathrm{C}$ composition; $\delta^{13} \mathrm{C}$ ) is commonly less than in the carbon of atmospheric carbon dioxide Farquhar et al. (1982). Plants have less ${ }^{13} \mathrm{C}$ than the atmospheric $\mathrm{CO}_{2}$, which is the source of photosynthetic carbon, due to the isotopic discrimination $\left(\triangle^{13} \mathrm{C}\right)$ that occur in the physical and chemical process during the incorporation of $\mathrm{CO}_{2}$ in the plant biomass. This discrimination occurs in the isotopic composition of plant tissue and generally, plants show a positive discrimination $(\Delta)$ against ${ }^{13} \mathrm{C}$. Natural $\mathrm{C}_{3}$ plants have a discrimination of $\sim 20 \times 10^{-3}$ or $20 \%$.

$\Delta{ }^{13} \mathrm{C}$ gives an integrated indicator of photosynthetic activity (Farquhar et al., 1982; Dawson et al., 2002); from the leaf tissue formation and through it, it is possible to trace the photosynthetic activity of the plants. When the plants are subjected to drought stress and close their stomata partially or totally, the partial pressure of $\mathrm{CO}_{2}$ into the leaf (ci) decreases and decreases discrimination of ${ }^{13} \mathrm{C}$. Therefore, by measuring the $\Delta^{13} \mathrm{C}$ of leaves formed during a period it is possible to deduce the behavior of photosynthesis and stomatal conductance, the higher the value of $\Delta$ implies high rate of photosynthesis and stomatal conductance. Nevertheless, variation in $\delta^{13} \mathrm{C}$ may depend on several other factors than water avail- ability. Warren et al. (2001), in a study on the availability of water and the $\delta^{13} \mathrm{C}$ in leaves and wood of conifers, documented that the $\delta^{13} \mathrm{C}$ is also affected by factors such as interception of radiation and concentration of nutrients as well as by water availability. Evaporation and transpiration processes cause a clear oxygen isotopic enrichment in soil and leaves, in the soil-plant system. Aravena and Acevedo (1985) linked this isotopic enrichment to the source of different isotopic species in the liquid-vapor system. The isotopic composition of oxygen in the tissues of the plant $\left(\delta^{18} \mathrm{O}\right)$ reflects the variation in $\delta^{18} \mathrm{O}$ of the source caused by evaporative enrichment, leaf transpiration water and biochemical fractionation occurring during the synthesis of organic matter (Farquhar and Lloyd, 1993). High stomatal conductance of plants is associated with low $\delta^{18} \mathrm{O}$ in the same environmental conditions. On the other hand, in water deficit situations, low stomatal conductance tends to be associated with a high $\delta{ }^{18} \mathrm{O}$ (Barbour, 2007). $\Delta^{13} \mathrm{C}$ and $\delta^{18} \mathrm{O}$ are negatively correlated if $\Delta^{13} \mathrm{C}$ varies due to changes in the stomatal conductance (Cernusak et al., 2005). However, there is no relationship between $\Delta^{13} \mathrm{C}$ and $\delta^{18} \mathrm{O}$ if the variation in $\Delta{ }^{13} \mathrm{C}$ is produced by a variation in photosynthetic capacity. Low ${ }^{13} \mathrm{C}$ discrimination and more enriched ${ }^{18} \mathrm{O}$ was found by Garrido et al. (2016) in leaf tissue of Prosopis tamarugo subjected to stress due to increased ground water table depth in the Pampa of Tamarugal.

\subsection{Hydraulic drivers of P. tamarugo plant growth}

Growth in plant can be defined as an irreversible increase in size. Plant growth has two principal aspects; a primary growth that includes growth in length of shoots and roots; and a secondary growth, which implicate the subsequent growth in thickness of stem and root (Ray, 1965). These kinds of growth are accomplished because new cells are continually produced by 
cell division in the meristems. Growth in shoots and roots is localized in regions at the tips of these organs. Regions with expanding tissue are called growth zones. Cell growth implies numerous metabolic aspects and can be defined as an irreversible expansion of cells. Cell expansion is possible because of synthesis of membranes, organelles, proteins and cell-wall materials always associated with differentiation at the subcellular level (Hsiao and Acevedo, 1974). Additionally, turgor pressure has an important role in the expansive growth. A hydrostatic pressure, acting as the push from inside is always necessary for the final expansion process, after the cell division and/or when the cell is metabolically prepared to expand. Growth of plant cells depends upon turgor pressure and is prevented by conditions that cause loss of turgor. A positive turgor pressure $(\Psi \mathrm{p})$ in growth is important for two principal reasons. First, growth of plant cells requires turgor pressure to stretch the cell walls. The loss of $\Psi$ p under water deficits can explain in part why cell growth is so sensitive to drought stress. The second reason positive turgor is important is that turgor pressure increases the mechanical rigidity of cells and tissues. This function of cell turgor pressure is particularly important for young, nonlignified tissues, which cannot support themselves mechanically without a high internal pressure (Taiz and Zeiger, 1998). Furthermore, growth is extremely sensitive to small water deficit because the enlargement of cells during growth depends on two simultaneously occurring processes, the uptake of water and the increase in area of the cell wall (Nobel, 2009). Water uptake involves spontaneous water movement towards sites of lower water potential while the irreversible aspect of growth depends on the yielding of the cell wall material. In this way, Green (1968) in experiments with Nitella found that any change in turgor pressure causes immediate changes in growth rate.
A simple equation (Equation 1) of Green (1968), that is always used to describe growth of cells, can explain in a best way the extreme sensitivity of growth to drought stress:

$$
G R=m\left(\Psi_{p}-\Psi_{t h}\right) \quad \text { Equation } 1
$$

where GR is growth rate, $\mathrm{m}$ is the cell wall extensibility, $\Psi \mathrm{p}$ is tugor pressure and $\Psi$ th is turgor threshold bellow which growth will not occur.

According to this equation, growth is proportional to cell extensibility that includes metabolic events that soften the wall and provide building blocks for expanding the cell, and to turgor pressure above a threshold level. The threshold turgor values can be high, as 0.6 or $0.8 \mathrm{Mpa}$ (Boyer, 1968). Growth tends to stop before $\Psi \mathrm{p}$ falls to zero, as consequence of a finite threshold turgor in developing drought stress situation (Hsiao and Acevedo, 1974).

However, Green et al 1971 evidenced that the cell extensibility and the turgor threshold are not constants, they may change with changes in water status in a way to facilitate growth under drought stress, and the stress may increase the extensibility and decrease the turgor threshold. If a plant has the ability to raise its extensibility and lower its threshold turgor, it could be able to maintain better its growth under water deficit conditions. It has been evidenced that, under drought stress situations, any amount of adjustments in these two parameters in the equation could allow growth restitution when the turgor pressure falls to zero (Green et al., 1971). Nevertheless, some plants have the ability to maintain some growth through osmoregulation. Acevedo et al. (1985a), evidenced, through pressure-volume curves, that Prosopis tamarugo has the ability to perform osmotic adjustment and maintains a high relative water content in the leaves at low 
values of water potential, favoring a positive pressure potential and keeping active its metabolism. They found turgor pressure at about $0.8 \mathrm{MPa}$ when the soil water potential varied from -0.06 to $-3.0 \mathrm{MPa}$.

Water makes up most of the mass of plant cells and each cell contains a large water-filled vacuole. In such cells the cytoplasm makes up only 5 to $10 \%$ of the cell volume; the remainder is vacuole. Water is the most abundant resource that plants need to grow and function; it typically constitutes 80 to $95 \%$ of the mass of growing plant tissues. Cell growth is strongly influenced by water potential and its components, the water potential governs transport across cell membranes, and it is often used as a measure of the water status of a plant (Taiz and Zeiger, 1998).

The water absorbed by the roots and transported by the xylem of the tree is transpired by the leaves. However, during the night, when the stomata are closed the water status of the tree is recovered, showing an increase in water potential during the night until dawn (Caldwell \& Richards, 1986). The water potential at pre-dawn is then the maximum water potential obtained by the tree in a day-night cycle (León, 2002). Water potential decrease has been observed in conditions of drought stress, both at midday and at predawn in individuals of Prosopis tamarugo (Garrido et al., 2016, Time, 2017). Water potential ( $\left.\Psi_{\mathrm{w}}\right)$ is also a measure of how hydrated a plant is and thus provides a relative index of the drought stress the plant is experiencing. In leaves of well-watered plants, $\Psi_{\mathrm{w}}$ ranges from -0.2 to about $-1.0 \mathrm{MPa}$, but the leaves of plants in arid climates can have much lower values, perhaps -2 to $-5 \mathrm{MPa}$ under extreme conditions (Taiz and Zeiger, 1998).

Twig growth is directly related to the water status required for cell elongation and development. Ortiz (2010), in a study conducted in tamarugos exposed to different depths of the water table as a result of anthropogenic extraction, found a negative association between the percentage of green cover (visual notes) and water table depth. This is consistent with a report by Ortiz et al. (2012) who negatively associated tamarugo activity (measured as normalized difference vegetation index, NDVI) with the water table depth, reaching minimum values of activity (NDVI $=0.1$ ) when the water table depth exceeded $10 \mathrm{~m}$. Under similar conditions, Squella (2013) reported a negative association between the growth of tamarugo shoots and water table depth, suggesting a threshold value of $11.7 \mathrm{~m}$ depth at which the growth of twigs ceased. These results indicate that under drought stress, tamarugo activates mechanisms by which it reduces the transpiring surface through defoliation (Chavez et al., 2013; Ortiz et al., 2012) and growth arrest (Squella, 2013). Growth arrest was observed at a water potential of $-3,16 \mathrm{MPa}$ under experimental condition in a water shortage treatmentfor 21 days (Time, 2017). The latter could be associated with changes in the partition coefficient, prioritizing for example, reserves storage and/or root growth. Squella (2013) also reported an increase in $\delta^{18} \mathrm{O}$ of the leaf tissues as the water table increased its depth, indicating a lower stomatal conductance at a seasonal scale. Twenty meters of ground water depletion was suggested by Chavez et al. (2016) to be the critical threshold for the survival of tamarugo trees in the Pampa of Tamarugal. The tamarugo trees tend to have a differential response to a similar drop of the water table (Ortiz et al, 2012; Chavez et al, 2013b), so that the study of individual trees is necessary, particularly considering that mature trees (i.e. bigger in size) have a number of features that help them maintain their homeostasis under stress. These features are higher contents of internal water (capacitance), greater carbohydrate reserves, bigger root systems, lower transpiration to leaf area ratio, among others (McDowell et al., 2011). The trees can also vary in their genetic makeup.

Chavez et al. (2016) reported that the normalized difference vegetation index in winter and the normalized 
difference vegetation index between mean winter and summer of the Tamarugo forest declined on average $19 \%$ and $51 \%$, respectively, while ground water depleted on average $3 \mathrm{~m}$ over the period 1988-2013. About $5.2 \%$ of plants identified in the study area showed a green canopy fraction (GCF) inferior to 0.25 , which was associated with severe drought stress (Chavez et al., 2016; Decuyper et al., 2016). Furthermore, limited paraheliotropic leaf movement, dehydration and foliage loss was found to be associated to a ground water depletion inferior to $12 \mathrm{~m}$ (Chavez et al., 2016). Other data showing how groundwater can induce diverging sensitivity of forest growth and survival to climate variability have been reported by Bogino et al, (2011) in other Prosopis in the Argentinian pampas. Where ground water increased growth at optimum depths about 2-8 meters but depressed it or even killed trees when it approaches the surface inferior to 2 meters, according to this study.

\section{Concluding Remarks}

Prosopis tamarugo is under threat of extinction, because it is subjected to drought stress due to ground water extraction for urban areas, mining industry and agriculture supply, that is generating depletion of the water table of the aquifer (Rojas and Desargues, 2007), and generates an unbalance in the tamarugo water budget. However, tamarugo has the capacity to maintain high stomata conductance when subjected to increasing temperature and atmospheric water demand (Lehner et al., 2001; Delatorre et al., 2008). Chávez et al. (2013a) indicated that tamarugo is a plant capable of changing the angle of its leaflets in order to avoid high levels of radiation in the afternoon. Referring to drought stress, tamarugo aboveground growth is very sensitive to water deficit.
As some other plants that have the ability to maintain some growth through osmoregulation, which is a solutes accumulation in the cells that allows a positive turgor pressure development in spite of the low water potential, Prosopis tamarugo has the ability to perform osmotic adjustment and maintains a high relative water content in the leaves at low values of water potential, favoring a positive pressure potential and keeping active its metabolism. Under drought stress, tamarugo tends to decrease water loss by partially closing its stomata in search of a water balance. Through its anisohydric behavior, facing drought stress, tamarugo can maintain a stomatal conductance at low leaf water potential. Lastly, Tamarugo has the capacity to grow at low leaf water potential, its growth rate was still measurable at $-2,8$ and $-3,16 \mathrm{MPa}$ due to its anisohydric behavior and its capacity to adjust osmotically (Time, 2017). We recommend studies on hormonal balance of $P$. tamarugo under drought stress for a better understanding from a biomolecular view point of the tamarugo adaptation mechanism to drought stress.

\section{Acknowledgments}

Financial funding for this review was provided by the FONDECYT Project No 1150799 and the Soil-PlantWater Relations Laboratory of the Faculty of Agronomical Sciences of the University of Chile.

\section{References}

Acevedo, E., Pastenes, J. 1983. Distribución de Prosopis tamarugo Phil. en la Pampa del Tamarugal (Desierto de Atacama). Terra Aridae. 2, 317-335.

Acevedo, E., Sotomayor, D., Zenteno, V. 1985a. Parámetros hídricos de tejidos foliares de Prosopis tamarugo Phil. En: Estado Actual Sobre el Conocimiento de Prosopis tamarugo. Mario Habit (Ed.) 
Arica, Chile, 11-15 de Junio de 1984. FAO. 483 pp.

Acevedo, E., Sotomayor, D., Zenteno, V. 1985b. Antecedentes de mecanismos de fijación de $\mathrm{CO}_{2}$ en Prosopis tamarugo Phil. En: Estado Actual Sobre el Conocimiento de Prosopis tamarugo. Mario Habit (Ed.) Arica, Chile, 11-15 de Junio de 1984. FAO. 483 pp.

Acevedo, E., Sotomayor, D., Zenteno, V. 1985c. Parámetros ambientales y comportamiento hídrico de Prosopis tamarugo Phil. en la localidad de Refresco (Pampa del Tamarugal) En: Estado Actual Sobre el Conocimiento de Prosopis tamarugo. Mario Habit (Ed.) Arica, Chile, 1115 de Junio de 1984. FAO. 483 pp.

Acevedo, E., Ortiz, M., Franck, N., Sanguineti, P. 2007. Relaciones hídricas de Prosopis tamarugo Phil. Uso de isótopos estables Universidad de Chile Facultad de Ciencias Agronómicas. Serie Ciencias Agronómicas No. 14. 82 pp.

Allen, C.D., Macalady, A.K., Chenchouni, H., Bachelet, D., McDowell, N., Vennetier, M., Kitzberger, T., Rigling, A., Breshears, D.D., Hogg, E.H. 2010. A global overview of drought and heat-induced tree mortality reveals emerging climate change risks for forest. Forest Ecology and Management. $259,660-684$.

Aravena, R., Acevedo, E. 1985. Estudio de la relación hídrica de Prosopis tamarugo Phil. mediante isotopos estables, Oxígeno-18 y Deuterio. En: Estado Actual Sobre el Conocimiento de Prosopis tamarugo. Mario Habit (Ed.) Arica, Chile, 11-15 de Junio de 1984. FAO. pp: 251-256.

Barbour, M. 2007. Stable oxygen isotope composition of plant tissue: a review. Functional Plant Biology. $34,83-94$.

Blackman, P.G., Davies, W.J. 1985. Root to shoot communication in maize plants of the effects of soil drying. J. Exp. Bot. 36, 39-48.
Bogino, S.M., Jobbagy, E.G. 2011. Climate and groundwater effects on the establishment, growth and death of Prosopis caldenia trees in the Pampas (Argentina). For. Ecol. Manag. 262, 1766-1774.

Boyer, J.S. 1968. Relationship of water potential to growth of leaves. Plant Physiol. 43, 1056-1062.

Calderon, G., Garrido, M., Acevedo, E. 2015. Prosopis tamarugo Phil.: a native tree from the Atacama Desert groundwater table depth thresholds for conservation. Revista Chilena de Historia Natural. 88,18

Caldwell, M.M., Richards, J.H. 1986. Competing root systems: morphology and models of absorption. On the Economy of Plant Form and Function (Ed. by T. J. Givnish), Cambridge University Press, Cambridge.pp. 251-273.

Chapin, F.S.III. 1980. The mineral nutrition of wild plants. Annu. Rev. Ecol. Syst. 11, 233-260.

Chapin, F.S. III., Wardlaw, I.F. 1988. Effect of phosphorus deficiency on source-sink interactions between the flag leaf and developing grain of barley. J. Exp. Bot. 39, 165-177.

Chapin, F.S.III. 1991. Integrated Responses of Plants to Stress, A centralized system of physiological response. BioScience, Vol. 41, No. 1 (Jan., 1991), pp. 29-36. http://www.jstor.org/stable/1311538.

Chávez, R., Clevers, J.G., Herold, M., Ortiz, M., Acevedo, E. 2013a. Modelling the spectral response of the desert tree Prosopis tamarugo to water stress. International Journal of Applied Earth Observation and Geoinformation. 21, 53-61.

Chávez, R., Clevers, J.G., Herold, M., Acevedo, E., Ortiz, M. 2013b. Assessing water stress of Desert Tamarugo Trees Using in situ Data and Very High Spatial Resolution Remote Sensing. Remote Sensing. 5, 5064- 5088.

Chávez, R.O., Clevers, J.G.P.W., Decuyper, M., De Bruin, S., Herold, M., 2016. 50 years of ground- 
water extraction in the Pampa del Tamarugal basin: can Tamarugo trees survive in the hyper-arid Atacama Desert? J. Arid. Environ. 124, 292-303.

Chaves, M.M., Pereira, J.S., Maroco, J., Rodrigues, M.L., Ricardo, C.P.P., Osorio, M.L., Carvalho, I., Faria, T., Pinheiro, C. 2002. How plants cope with water stress in the field? Photosynthesis and growth. Annals of Botany. 89, 907-916.

Cernusak, L., Farquhar, G., Pate, J. 2005. Environmental and physiological controls over oxygen and carbon isotope composition of Tasmanian blue gum, Eucalyptus globules. Tree Physiology. 25, 129-146.

Cooper, D., D’Amico, R., Scott, M. 2003. Physiologi$\mathrm{cal}$ and morphological response patterns of $\mathrm{Popu-}$ lus deltoides to alluvial ground water pumping. Environ. Manage. 31, 215-226.

Dawson, T., Mambelli, S., Plamboeck, A., Templer, P., Tu, K. 2002. Stable isotopes in plant ecology. Annual Review of Ecology and Systematics. 33, 507-559.

Decuyper, M., Chavez, R.O., Copini, P., Sass-Klaassen, U., 2016. A multi-scale approach to assess the effect of groundwater extraction on Prosopis tamarugo in the Atacama Desert. J. Arid Environ. $131,25-34$.

Delatorre, J., Pinto, M., Cardemil, L. 2008. Effects of water stress and high temperature on photosynthetic rates of two species of Prosopis. Journal of Photochemestry and Phothobiology. 92, 67-76.

Evans, J.R. 1989. Photosynthesis and nitrogen relationships in leaves of $\mathrm{C} 3$ plants. Oecologia. 78, 9-19.

Farquhar, G., O'leary, M., Berry, J. 1982. On the relationship between carbon isotope discrimination and the intercellular carbon dioxide concentration in leaves. Functional Plant Biology. 9, 121-137.

Farquhar, G., Lloyd, J. 1993. Carbon and Oxygen isotope effects in the exchange of carbon dioxide between terrestrial plants and the atmosphere.
Stable Isotopes and plant carbon-water relations. Ehleringer, J., Hall, A. and Farquhar, G. San Diego, EEUU, Academic Press. 555 pp.

Flexas, J., Diaz-Espejo, A., Gago, J., Gallé, A., Galmés, J., Gulías, J., Medrano, H. 2014. Photosynthetic limitations in Mediterranean plants: a review. Environ. Exp. Bot. 103, 12-23.

Frelich, L. 2002. Forest Dynamics and Disturbance Regimes-Studies from Temperate EvergreenDeciduous Forests. Cambridge: Cambridge University Press.

Galera, F. 2000. Las especies del genero Prosopis (Algarrobos) de América Latina con especial énfasis en aquellas de interés económico. Córdoba, Argentina. 276 pp.

García, F. 2006. Introducción al funcionamiento de las plantas. Ed. Univ. Politéc. Valencia, España. $182 \mathrm{pp}$.

Garrido, M., Silva, P., Acevedo, E. 2016. Water relations and foliar isotopic composition of Prosopis tamarugo Phil., an endemc tree of the Atacama Desert Growing at Three Levels of Water Table Depth. Frontiers in Plant Science. doi: 10.3389/ fpls.2016.0037.

Green, P.B. 1968. Growth physics in Nitella: a method for continuous in vivo analysis in extensibility based on a micro-manometer technique for turgor pressure. Plant Physiol. 43, 1169-1184.

Green, P.B., Erickson, R.O., Buggy, J. 1971. Methabolic and physical control of cell elongation rate - in vivo studies in Nitella. Plant Physiol. 47, 423430.

Grime, J.P. 1977. Evidence for the existence of three primary strategies in plants and its relevance to ecological and evolutionary the- ory. Am. Nat. 111, 1169-1194.

Guan, B., Ge, Y., Fan, M., Niu, X., Lu, Y., \& Chang, J. 2003. Phenotypic plasticity of growth and morphology in Mosla chinensis responds to diverse 
relative soil water content. Acta Ecologica Sinica. 23, 259-563.

Habit, M. (Ed.) 1985. Estado Actual del Conocimiento sobre Prosopis tamarugo Phil. FAO. Oficina Regional para América Latina y El Caribe. 483 pp.

Hsiao, T.C. 1973. Plant responses to water stress. Ann. Rev. Plant Physiol. 24, 519-570.

Hsiao, T., Acevedo, E. 1974. Plants responses to water deficits, water use efficiency, and drought resistance. Agricultural Meteorology. 14, 59-84.

Hsiao, T.C., Fereres, E., Acevedo, E., Henderson, D.W. 1976. Water stress and dynamics of growth and yield of crop plants. Pages 281-305 in 0. L. Lange, L. Kappen, and E.-D. Schulze, eds. Water and Plant Life. Problems and Modern Approaches. Springer-Verlag, New York.

Khalatbari, A.A., Jaafar, H.Z.E., Khalatbri, A.M., Mahmood, M., Othman, R. 2015. Wild type and vte 4 mutant Arabidopsis thaliana responses to different water frequencies : genetic engineering towards stress tolerance. Journal of Soil Science and Plant Nutrition. 15, 991-1006.

Lambers, H., Chapin, F.S.III., Pons, T.L. 1998. Photosynthesis, respiration, and long distance transport. In: Lambers H, Chapin FS III., Pons TL., eds. Plant physiological ecology. Berlin, Germany: Springer Verlag, 10-95.

Lee, R.B. 1982. Selectivity and kinetics of ion uptake by barley plants following nutrient deficiency. Ann. Bot. 50, 429-449.

Lehner, G., Delatorre, J., Lutz, C., Cardemil, L. 2001. Field studies on the photosynthesis of two desert Chilean plants: Prosopis chilensis and Prosopis tamarugo. Journal of Photochemistry and Photobiology B: Biology. 64, 36-44.

León, M. 2002. ¿Hay ocurrencia de levantamiento hidráulico en los arbustos nativos del secano costero del Norte Chico de Chile? Seminario de título para optar al título de Ingeniero Agrónomo y al grado académico de Licenciado en Agronomía. Departamento de Agronomía, Facultad de ciencias, Universidad de la Serena. 141 pp.

Mandre, M. 2002. Stress concepts and plants. Forestry Studies, 36, 9-17.

McDowell, N., Pockman, W.T., Allen, C.D., Cobb, N., Kolb, T., Plaut, J., Sperry, J., West, A., Williams, D.G. 2008. Mechanism of plant survival and mortality during drought: why do some plants survive while others succumb to drought? New Phytologist. 178, 719-739.

McDowell, N., Beerling, D., Breshears, D., Fisher, R., Raffa, K., Stitt, M. 2011. The interdependence of mechanisms underlying climate-driven vegetation mortality. Trends Ecol. Evol. 26, 523-532.

Ministerio del Medio Ambiente, Gobierno de Chile MMA, 2012. Clasificación de especies, fichas de proceso, Prosopis tamarugo. $6 \mathrm{pp}$.

Ministerio de Agricultura, Gobierno de Chile MINAGRI, 2006. Plan de Conservación y Manejo del Tamarugo (Prosopis tamarugo Phil.). Edit.: César Cardozo Rojas y Enrique Miranda Franulic.

Mitchell, P.J., O'Grady, A.P., Tissue D.T., Worledge, D., Pinkard, E.A. 2014. Co-ordination of growth, gas exchange and hydraulics define the carbon safety margin in tree species with contrasting drought strategies. Tree Physiology, 34:443-458.

Morgan, J.M. 1984. Osmoregulation and water stress in higher plants. Annu. Rev. Plant Physiol. 35, 299-319.

Munns, R., Greenwa, H., Delane, R., Gibbs, J. 1982. Ion concentration and carbo-hydrate status of the elongating leaf tissue of Hordeum vulgare growing at high external $\mathrm{NaCl}$. J. Exp. Bot. 33, 574-583.

Nobel, P.S. 2009. Physicochemical and Environmental Plant Physiology. 5th edition. Academic Press, San Diego. 488 pp. 
Ortiz, M., Morales, L., Silva, P., Acevedo, E. 2012. Estimación del nivel freático a partir del NDVI Landsat en la Pampa del Tamarugal (Chile). Revista de Teledetección. 37, 42-50.

Ortiz, M. 2010. Nivel Freático en la Pampa del Tamarugal y crecimiento de Prosopis tamarugo Phil. Tesis doctoral programa de doctorado en ciencias silvoagropecuarias y veterinarias, Universidad de Chile. 92 pp.

Patrick, J.M., Anthony, P.O., David, T.T., Donald, A.W., Maria, L.O., Elizabeth, A.P. 2013. Drought response strategies define the relative contributions of hydraulic dysfunction and carbohydrate depletion during tree mortality. New Phytologist. 197, 862-872.

Pinkard, E.A., Eyles, A., O'Grady, A.P. 2011. Are gas exchange responses to resource limitation and defoliation linked to source: sink relationships? Plant Cell Environment. 34,1652-1665.

Ray, P.M. 1965. The Living Plant. University of Michigan. 127 pp.

Richards, J., Cladwell, M. 1987. Hydraulic lift: substantialnocturnal water transport between soil layers by Artemisia tridentate roots. Oecología. 73, 486-489.

Rojas, R., Dassargues, A. 2007. Groundwater flow modelling of the regional acquifer of the Pampa del Tamarugal, northern Chile. Hydrogeology Journal. 15, 537-551.

Rood, S., Zanewich, K., Stefura, C., Mahoney, J. 2000. Influence of water table decline on growth allocation and endogenous gibberellins in black cottonwood. Tree Physiology. 20, 831-836.

Sanchez-Blanco, M.J., Rodriguez, P., Morales, M.A., Ortuño, M.F., Torrecillas, A. 2002. Comparative growth and water relations of Cistus albidus and Cistus monspeliensis plants during water deficit conditions and recovery. Plant Science. 162, 107113.
Schimel, J., Balser, T.C., Wallenstein, M. 2007. Microbial stress response physiology and its implications for ecosystem function. Ecology. 88, 1386-1394.

Squella, C.E.F. 2013. Respuestas de tamarugo (Prosopis tamarugo Phil) a un estado hídrico decreciente en el Salar de Llamara. Tesis de Magister en Ciencias Agropecuarias, Mención Producción de Cultivos, Facultad de Ciencias Agronómicas, Universidad de Chile, 94 pp.

Sudzuki, F. 1985. Influencia del medio ambiente sobre la anatomía foliar de Prosopis tamarugo Phil. En: Estado actual sobre el conocimiento de Prosopis tamarugo Phil. Mario A. Habit (Ed.) Arica, Chile, 11-15 Junio de 1984. FAO. 483 pp.

Taiz, L., Zeiger, E. 1998. Plant Physiology. Sunderland, Massachusetts. Sinauer Associates, Inc. Tanksley SD and McCouch, SR (1997). Seed banks and molecular maps: unlocking genetic potential from the wild. Science. 277, 1063-1066.

Tardieu, F., Simonneau, T. 1988. Variability among species of stomatal control under fluctuating soil water status and evaporative demand: modeling isohydric and anisohydric behaviours. J. Exp. Bot. 49, 419-432.

Time, A., 2017. Determination of Prosopis tamarugo Phil growth response to water stress. Tesis de Magister en Ciencias Agropecuarias, Facultad de Ciencias Agronómicas, Universidad de Chile, $53 \mathrm{pp}$.

Valladares, F. 2004. Ecología del bosque mediterráneo en un mundo cambiante. P. 163-190. Ministerio de Medio Ambiente, EGRAF, S.A., Madrid. ISBN: 84-8014-552-8.

Wardlaw, I.F. 1969. The effect of water stress on translocation in relation to photosynthesis and growth. II. Effect during leaf development in Lolium temulentum. L. Aust. J. Biol. Sci. 22, 1-16. 
Warren, C., McGrath, J., Adams, M. 2001. Water availability and carbon isotope discrimination in conifers. Oecologia. 127, 476-486.

Williams, A., Allen, C., Macalady, A., Griffin, D., Woodhouse, C., Meko, D. 2013. Temperature as a potent driver of regional forest drought stress and tree mortality. Nat. Clim. Change. 3, 292-297.
Xue, R., Shen, Y., Marschner, P. 2016. Low soil water content during plant growth influences soil respiration and microbial biomass after plant removal and rewetting. Journal of Soil Science and Plant Nutrition. 16, 955-966. 